\title{
Provenance of detrital tourmalines from Proterozoic metasedimentary rocks in the Picuris Mountains, New Mexico, using Laser-Induced Breakdown Spectroscopy
}

\author{
Shoshauna FARNSWORTH-PINKERTON ${ }^{1 *}$, Nancy J. MCMILLAN ${ }^{1}$, Barbara L. DUTROW ${ }^{2}$, \\ Darrell J. HENRY² \\ ${ }^{1}$ Department of Geological Sciences, New Mexico State University, Box 30001, MSC 3AB, Las Cruces, New Mexico 88003, USA; \\ sfarns2@lsu.edu \\ 2 Department of Geology \& Geophysics, Louisiana State University, Baton Rouge, LA, 70803, USA \\ * Corresponding author
}

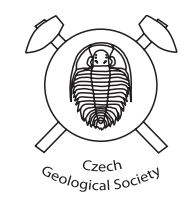

Tourmaline is a useful mineral for determining provenance of sediments. Here, detrital tourmaline has been used to evaluate provenance for the Rinconada and Piedra Lumbre formations in the Copper Hill Anticline, Picuris Mountains, New Mexico, USA to assess the existence of the Mesoproterozoic Picuris Orogeny. This orogeny has been proposed by other authors based on the presence of 1600-1475 Ma detrital zircons in the Piedra Lumbre Formation of the Hondo Group and Yavapai age (1780-1700 Ma) detrital zircons in units underlying the Piedra Lumbre Formation, including the Rinconada Formation.

Optically distinct detrital cores of tourmaline grains from the Rinconada and Piedra Lumbre formations were analyzed using Laser-Induced Breakdown Spectroscopy (LIBS) to establish likely lithologic sources. A total of 209 LIBS spectra of detrital grains were collected from the Rinconada Formation, 50 of which were tourmaline. Based on multivariate analysis of these 50 tourmalines, 24 are most likely from pelitic metamorphic rocks, four from calcareous metamorphic rocks, eight from Li-poor pegmatites and silicic igneous rocks, and 14 from hydrothermal rocks. In contrast, none of the 3274 LIBS spectra collected from the Piedra Lumbre Formation were from tourmaline.

Source regions for the Rinconada and Piedra Lumbre formations are interpreted to be different due to the presence of tourmaline in the Rinconada Formation and its absence in the Piedra Lumbre Formation. Based on detrital tourmaline data, evidence for a change in provenance supports the proposed Picuris Orogeny.

Keywords: Laser-Induced Breakdown Spectroscopy (LIBS), tourmaline, provenance, Picuris Mountains, Rinconada Formation, Piedra Lumbre Formation

Received: 31 October, 2017; accepted: 3 June, 2018; handling editor: M. Novák

\section{Introduction}

Proterozoic growth of the Laurentian continent southward is thought to have occurred during two major orogenies: the Yavapai Orogeny at 1780-1700 Ma and the Mazatzal Orogeny at 1680-1600 Ma (e.g. Karlstrom and Bowring 1988; Bowring and Karlstrom 1990; Whitmeyer and Karlstrom 2007). The Precambrian Hondo Group rocks of the Picuris Mountains in northcentral New Mexico, USA, have long been interpreted as shallow marine sediments that were metamorphosed during the Mazatzal Orogeny (Fig. 1; e.g. Barrett and Kirschner 1979; Soegaard and Eriksson 1985, 1989; Bauer 1993). The Rinconada and Piedra Lumbre formations comprise the upper Hondo Group. The Rinconada Formation consists of alternating phyllites, metaquartzites, and pelitic schists (Bauer 1984). The Piedra Lumbre Formation is a carbonaceous muscovite-biotite phyllite with garnet porphyroblasts (Nielsen and Scott 1979; Bauer 1984).
Recent work proposed an additional Mesoproterozoic orogeny, the Picuris Orogeny at c. 1490-1400 Ma, based on detrital zircon evidence from the Rinconada and Piedra Lumbre formations (Daniel et al. 2013). Zircons from the Rinconada Formation (Fig. 2) have ages older than $1700 \mathrm{Ma}$ and are consistent with local Yavapai sediment sources. However, the overlying Piedra Lumbre Formation contains zircons with ages 1600-1450 Ma, in addition to those with Yavapai ages (1780-1700 Ma). Because no magmatism has been identified in the region between $1500 \mathrm{Ma}$ and $1600 \mathrm{Ma}$, these zircons indicate the existence of an additional clastic sediment source. Daniel et al. (2013) proposed that juxtaposition of this non-Laurentian source in the Piedra Lumbre Formation is evidence for a suturing event associated with the Picuris Orogeny.

This study tests the Picuris Orogeny hypothesis using detrital tourmaline in the Rinconada and Piedra Lumbre formations to determine possible changes in source rock lithologies. Multivariate analysis of Laser- 

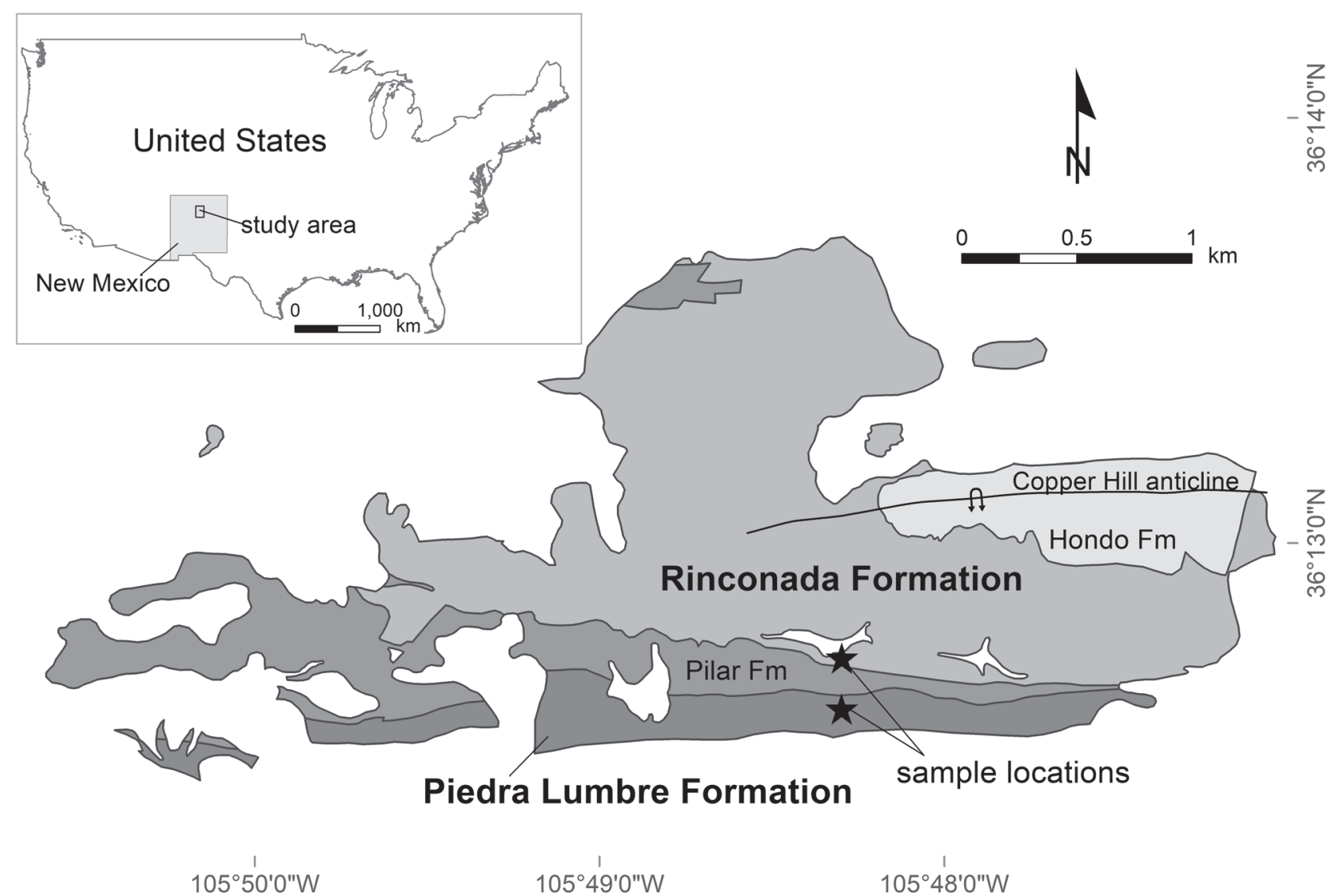

$105^{\circ} 49^{\prime} 0$ "W

$105^{\circ} 48^{\prime} 0^{\prime \prime} \mathrm{W}$

Fig. 1 Simplified geological map of the study area in the Picuris Mountains, New Mexico, USA after Bauer and Helper (1994). Stars indicate sample locations in the Rinconada and Piedra Lumbre formations.

Induced Breakdown Spectroscopy (LIBS) spectra is used to determine original host-rock lithology on detrital tourmalines. A change in sediment source region could be recorded by a change in detrital tourmaline composition.

\subsection{Tourmaline}

The chemical, physical and mechanical properties of tourmaline make it a useful mineral for provenance determinations (e.g. Krynine 1946). Tourmaline is a boron-bearing cyclosilicate with the general formula $\mathrm{XY}_{3} \mathrm{Z}_{6}\left(\mathrm{BO}_{3}\right)_{3} \mathrm{~T}_{6} \mathrm{O}_{18} \mathrm{~V}_{3} \mathrm{~W}$ (e.g. Henry et al. 2011). Typical elements are $\mathrm{Na}$ and $\mathrm{Ca}$ in the $\mathrm{X}$-site, $\mathrm{Li}, \mathrm{Mg}$, and $\mathrm{Fe}^{2+}$ in the $\mathrm{Y}$-site, $\mathrm{Mg}, \mathrm{Al}$, and $\mathrm{Fe}^{2+}$ in the $\mathrm{Z}$-site, and $\mathrm{OH}, \mathrm{F}$, and $\mathrm{O}$ in the $\mathrm{W}$-site (e.g. Hawthorne and Dirlam 2011).

The structure of the mineral allows for incorporation of numerous chemical constituents that respond to and record the chemical environment of formation (e.g. Henry and Guidotti 1985). This sensitivity can be useful for petrogenetic and provenance correlation (e.g. Viator 2003; Dutrow and Henry 2011; van Hinsberg 2011). Tourmaline is stable over a wide range of temperatures and pressures and is both physically and chemically stable in sedimentary conditions. Consequently, detrital tourmaline grains can be preserved in metasedimentary rocks as cores in tourmaline with metamorphic overgrowths (e.g. Henry and Dutrow 1992, 1996). The chemical signature of the detrital core reflecting its original host rock is also preserved because tourmaline has very slow diffusion rates (e.g. Henry and Dutrow 1992, 1996; Dutrow and Henry 2011).

Henry and Guidotti (1985) compiled chemical compositions of tourmaline from a variety of lithologies and found that tourmaline generally develops characteristic compositions when plotted on an $\mathrm{Al}-\mathrm{Fe}-\mathrm{Mg}$ discrimination diagram. As such, tourmalines that are separated from the original host lithology, such as detrital tourmaline grains, can be used as an indicator of the original host rock lithology. For example, Henry and Dutrow (1992) found that detrital tourmaline grains in chloritezone schists develop rims that are in equilibrium with the schists, but that the detrital cores retain their original lithologic chemical signature suggesting that over 20 sources contributed sediments in a single sample. Here, another method is used on the detrital cores to capture chemistry of tourmaline grains and to predict original 
tourmaline lithologies: Laser-Induced Breakdown Spectroscopy in conjunction with multivariate statistics.

\subsection{Laser-Induced Breakdown Spectroscopy}

Laser-Induced Breakdown Spectroscopy (LIBS) is a laser-ablation technique that collects the photon emission from microplasma generated by a laser pulse. Microplasma temperatures, $8,000-12,000 \mathrm{~K}$, cause excitation of free electrons that release photons when they return to lower energy levels as the plasma cools (e.g. Cremers and Radziemski 2006). The photons are collected by fiber optic cable, diffracted, and recorded by a charge-coupled device (CCD). Spectra, generally including ultraviolet, visible, and infrared light, contain information on all elements of a sample and can be considered a detailed chemical fingerprint (e.g. Harmon et al. 2009). In this study, the detailed LIBS fingerprint is used with multivariate statistics to determine host rock lithologies of detrital tourmaline.

\section{Methods}

\subsection{Sample collection and preparation}

Samples were collected from the Rinconada and Piedra Lumbre formations in the Copper Hill anticline in the Picuris Mountains, New Mexico, USA. Samples from the Rinconada Formation are from the R6 unit (Fig. 2). The R6 unit was selected because it was sampled for zircon analysis by Daniel et al. (2013).

To separate tourmalines, samples were disaggregated in

Fig. 2 Modified stratigraphic section of the study area with zircon ages from Daniel et al. (2013). Unit descriptions for the Hondo Group are from Nielsen and Scott (1979) and Bauer (1984). Stars indicate sample locations in the Rinconada and Piedra Lumbre formations.
(1)

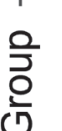

Rinconada
Formation
$<1.7 \mathrm{Ga}$

Ortega Formation $<1.7 \mathrm{Ga}$

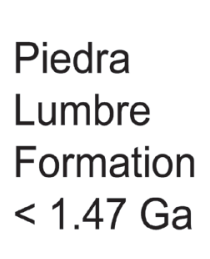

a steel jaw crusher and ground to sizes of $c .0 .5-8 \mathrm{~mm}$ with a steel disc grinder. Particles smaller than 0.595 $\mathrm{mm}$ were passed over a Gemini shaking table, allowing the heavy detritus to be collected. Further separation of minerals was accomplished using a Franz magnetic separator with settings at $0.30,0.50,0.80$, and $1.8 \mathrm{~A}$. Instead of hand-picking tourmalines from the remaining mineral separate, all the minerals collected from the 1.8 A setting were mounted in epoxy and ground to expose the crystal surfaces. Due to uneven crystal surfaces from the grinding process, additional samples from the mineral separate

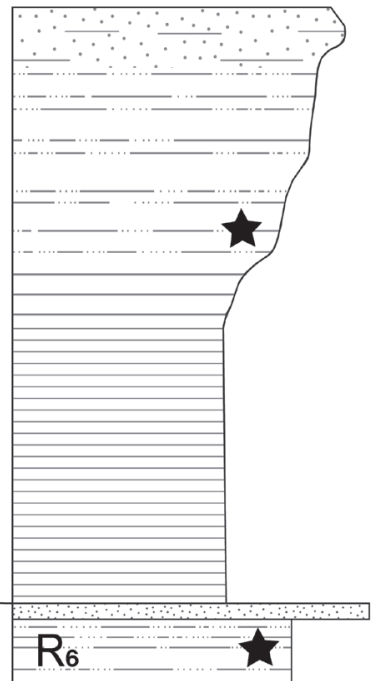

Carbonaceous muscovitebiotite phyllite with garnet porphyroblasts

\section{Graphitic phyllite}

Alternating phyllites, metaquartzites, and metapelitic schists

White to gray crossbedded quartzite 


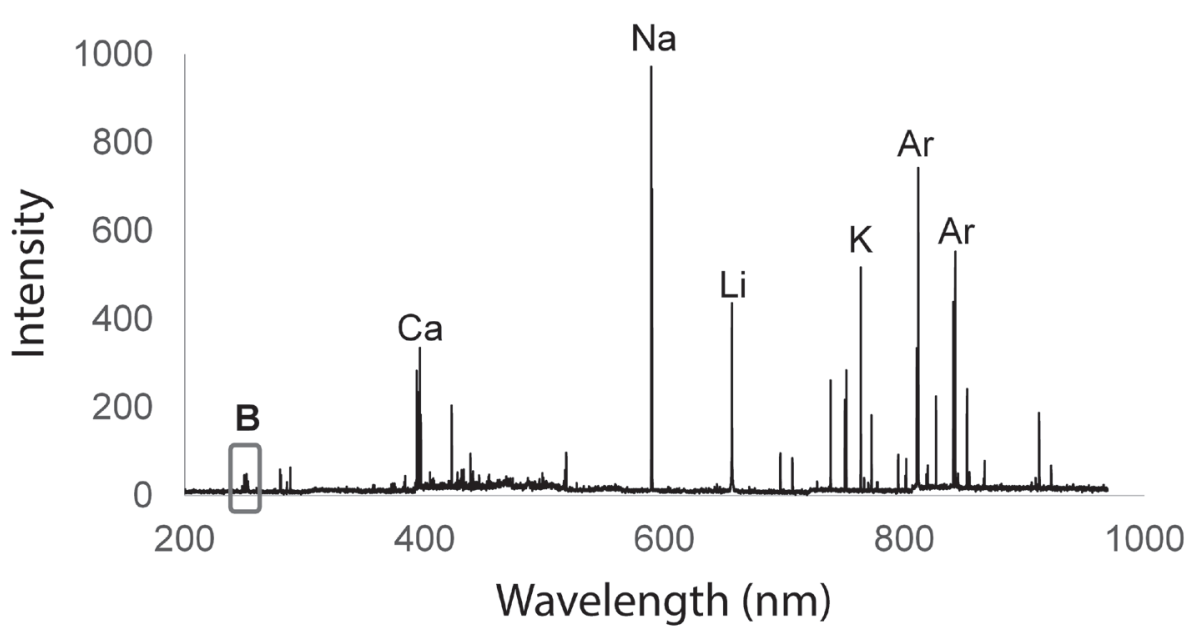

Fig. 3 Diagram showing a selected LIBS spectrum from a tourmaline grain in the sample from the Rinconada Formation. Major peaks are labeled with corresponding elements. Argon peaks are from the argon atmosphere used during analysis. Inside the box is the boron peak at $249.7 \mathrm{~nm}$ used to identify tourmaline. were prepared for LIBS analysis by adhering them to the sample tray with double-sided tape.

\subsection{Laser-Induced Breakdown Spectroscopy analysis}

Broadband LIBS spectra were acquired at New Mexico State University using an Ocean Optics 2500+ LIBS system with a Nd:YAG laser operated at its fundamental wavelength of $1064 \mathrm{~nm}$. Each pulse had a laser power of $63 \mathrm{~mJ}$. The Q-switch delay time was $1.5 \mu \mathrm{s}$; this is the time between the laser pulse and the beginning of light collection that allows the random kinetic processes that produce continuum radiation to decay prior to collection of quantum photons. The gate time width was $155 \mu \mathrm{s}$. Samples were analyzed in an argon atmosphere, which allows more excitation of atoms from the sample due to the high ionization energy of argon compared to analysis in air. Plasma light emissions between 200 and $1000 \mathrm{~nm}$ were collected. Selected peaks are labeled in the representative tourmaline LIBS spectrum presented in Fig. 3. The presence of a boron peak at $249.7 \mathrm{~nm}$ is used as a diagnostic indicator of tourmaline or another boron-rich phase. For analysis, the small size of the grains allowed only one pulse for each grain. The centers of grains were targeted; however, the optics of the system does not allow exact positioning of the laser spot on the sample. Thus, it is possible that some tourmaline rims were analyzed.

\subsection{Data analysis}

A matching algorithm for tourmaline LIBS spectra, developed by Curry (2015) using 169 tourmalines from five host rock types, was used to determine the original host rock lithology of the detrital grains. The algorithm is a series of binary partial least-squares regression (PLSR) models. These PLSR models consist of multiple linear regressions involving two matrices, typically called $\mathrm{X}$ and $\mathrm{Y}$ (Wold et al. 2001). The X matrix contains LIBS spectra and the $\mathrm{Y}$ matrix contains provenance variables. The provenance variables are 1 or 0 , where 1 indicates that the tourmaline belongs to the lithology being modeled and 0 indicates that it belongs to any of the other lithologies. Half of the spectra are used for calibration and the other half are used for test-set validation. The model is calibrated, or trained, using spectra with known lithology and provenance variables are calculated for all calibration spectra.

The Value of Apparent Distinction (VAD) is a provenance variable that separates the two groups, typically calculated as the average of the lowest provenance variable in the lithology being modeled (1) and the average of the highest provenance variable in the group of all other lithologies (0). If calculated provenance variables for validation spectra are greater than the VAD, then those spectra are classified as the lithology being modeled. If calculated provenance variables for validation spectra are less than the VAD, then the samples are classified as one of the other lithologic groups. The success rate for the model is the percent of correctly classified spectra. In the matching algorithm, the success rates for the models range from 94.1 to $96.9 \%$ (Curry 2015).

The PSLR models discriminate among five tourmalinebearing rock types based on the original sample set: calcareous metamorphic rocks, pelitic metamorphic rocks, hydrothermal deposits, Li-poor pegmatites and silicic igneous rocks, and Li-rich pegmatites (Fig. 4; Curry 2015). Li-rich pegmatites are distinguished from the Lipoor ones by the presence of a Li-saturated phase such as spodumene or lepidolite in the original rock. Silicic igneous rocks and $\mathrm{Li}$-poor pegmatites were modeled as a single group because the sample set did not contain a sufficient number of tourmalines from silicic igneous rocks to model that lithology as a separate group. The lithology with the most distinct composition is modeled 


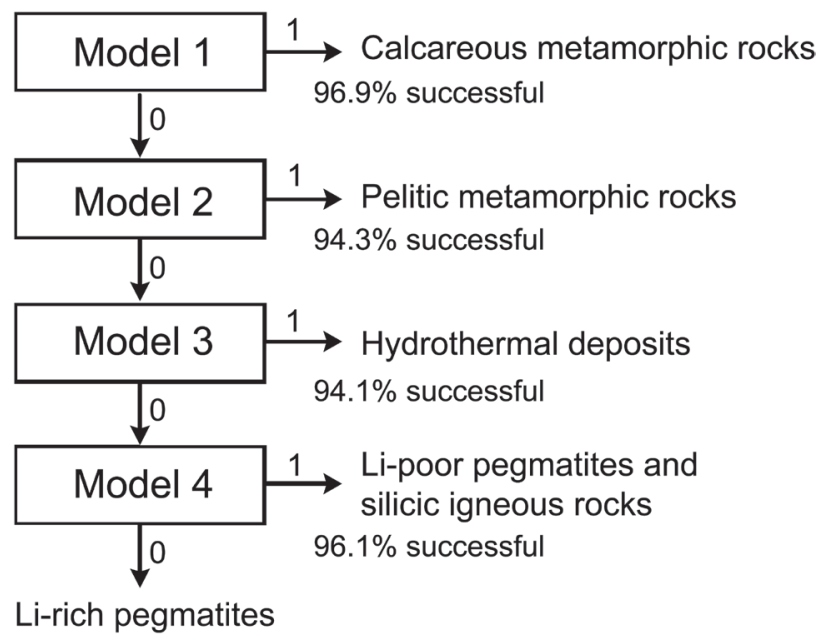

Fig. 4 Schematic of the matching algorithm used to determine tourmaline host rock lithology (Curry 2015). The algorithm is a series of PLSR models that were used to identify likely provenance for detrital tourmalines from the R6 unit in the Rinconada Formation.

first; spectra from that lithology are removed from all subsequent models. Thus, spectra become more similar as the algorithm progresses. This method has been successfully used to distinguish between limestone beds and to determine the countries of origin for rubies and sapphires (McMillan et al. 2012; Kochelek et al. 2015).

\section{Results}

\subsection{Rinconada Formation}

A total of 209 spectra were collected from grains of the R6 unit of the Rinconada Formation. Of these spectra, 50 were identified to be from tourmaline grains based on the presence of a significant boron peak at $249.7 \mathrm{~nm}$ (e.g. Fig. 3). Many of the remaining spectra from the Rinconada Formation were likely to be biotite due to the abundance of biotite in the mineral separate after magnetic separation.

These 50 tourmaline spectra were subjected to a series of PLSR models to identify the likely tourmaline host rock. Analyses demonstrate that 24 spectra were likely derived from pelitic metamorphic rocks, four from calcareous metamorphic rocks, eight from Li-poor pegmatites and silicic igneous rocks, and 14 from hydrothermal lithologies. None of the tourmaline spectra were classified as being derived from a Li-rich pegmatite.

\subsection{Piedra Lumbre Formation}

A total of 3274 spectra were collected from the Piedra Lumbre Formation. Based on the absence of the boron peak, none them was found to be tourmaline. Like the
Rinconada Formation, many of the spectra from the Piedra Lumbre Formation were likely to be biotite due to the abundance of biotite in the mineral separate after magnetic separation.

\section{Discussion and conclusions}

The presence of tourmaline in the R6 unit of the Rinconada schist suggests that at least four different host-rock types, including pelitic metamorphic rocks, Li-poor pegmatites and silicic igneous rocks, calcareous metamorphic rocks, and hydrothermal deposits contributed tourmaline detritus to the metasediment. The variety of detrital tourmaline sources recognized in the R6 sample is similar to the results of Henry and Dutrow (1992) that suggests numerous sources typically contribute to basin sediments.

In contrast, the lack of tourmaline in the Piedra Lumbre Formation suggests that tourmaline-absent host rocks contributed clastic sediments. Thus, a change in sediment source of the detritus is likely. Because the Rinconada and Piedra Lumbre formations are both metapelitic, the absence of tourmaline in the Piedra Lumbre Formation heavy mineral suite is an unexpected observation. Sample processing bias can be ruled out because the same mineral separation techniques were used for both samples.

Results of this study are consistent with the detrital zircon age data from Daniel et al. (2013) indicating a change in sediment source between the deposition of the Rinconada Formation (>1700 Ma) and the overlying Piedra Lumbre Formation (1600-1450 Ma). While the original goal of the study was to evaluate a difference in the lithologies that contributed sediment to the two formations, the presence of detrital tourmaline in the Rinconada Formation and its absence in the Piedra Lumbre Formation is a fundamental observation of this work and is strongly suggestive of a change in sediment sources. Thus, this LIBS tourmaline provenance study further supports the concept of the c. 1490-1400 Ma Picuris Orogeny (Daniel et al. 2013). This study suggests that the application of multivariate analysis of LIBS spectra from detrital tourmaline has promise as a tool for determining sediment provenance.

Acknowledgements. The authors wish to thank Jennifer White for providing laboratory assistance. We are indebted to colleagues who donated samples (to Dutrow) that were used in developing the original matching algorithm. We are grateful to the reviewers Kate McManus and Russell Harmon, the handling editor Milan Novák, and the editor-in-chief Vojtěch Janoušek for critical and helpful comments that aided in improving the manuscript. This research was funded by a grant from New Mexico Geological Society (NMGS) and a scholarship for under- 
graduate research from the New Mexico State University College of Arts and Sciences Discovery Scholars Program (DSP) to Shoshauna Farnsworth-Pinkerton. Portions of this study benefited from National Science Foundation funding to BD and DH (grant number EAR-1551434).

\section{References}

BARRett ME, Kirschner CE (1979) Depositional systems in the Rinconada Formation (Precambrian), Taos County, New Mexico. In: Ingersoll RV, WoOdWARd LA, JAMES, HL (eds) Santa Fe Country. New Mexico Geological Society Fall Field Conference Guidebook 30: 121-126

BAUER PW (1984) Stratigraphic summary and structural problems of Precambrian rocks, Picuris Range, New Mexico. In: BALdRIDGe WS, Dickerson PW, Riecker RE, ZIDEK J (eds) Rio Grande Rift: Northern New Mexico. New Mexico Geological Society Fall Field Conference Guidebook 35: 199-204

BAUER PW (1993) Proterozoic tectonic evolution of the Picuris Mountains, northern New Mexico. J Geol 101: 483-500

BAuer PW, HelPer MA (1994) Geology of Trampas Quadrangle, Picuris Mountains, Taos and Rio Arriba Counties, New Mexico. Geologic map 71, New Mexico Bureau of Mines and Mineral Resources, Socorro

Bowring SA, KARLSTROM KE (1990) Growth, stabilization, and reactivation of Proterozoic lithosphere in the southwestern United States. Geology 18: 1203-1206

Cremers DA, RADZIEMSKi LI (2006) Handbook of LaserInduced Breakdown Spectroscopy. Wiley, Chichester, pp 1-283

CURRY JC (2015) Tourmaline Provenance: Application of Laser-Induced Breakdown Spectroscopy and Chemometric Analysis. Unpublished MSci thesis, New Mexico State University, Las Cruces, pp 1-105

Daniel CG, Pfeifer LS, Jones JV, McFarlane CM (2013) Detrital zircon evidence for non-Laurentian provenance, Mesoproterozoic (c. 1490-1450 Ma) deposition and orogenesis in a reconstructed orogenic belt, northern New Mexico, USA: defining the Picuris Orogeny. Geol Soc Am Bull 125: 1423-1441

Dutrow BL, Henry DJ (2011) Tourmaline: a geologic DVD. Elements 7: 301-306

Harmon RS, Remus J, McMillan NJ, McManus C, Collins L, Gottfried JL, Delucia FC, Miziolek AW (2009) LIBS analysis of geomaterials: geochemical fingerprinting for the rapid analysis and discrimination of minerals. Appl Geochem 24: 1125-1141

Hawthorne FC, Dirlam DM (2011) Tourmaline the indicator mineral: from atomic arrangement to Viking navigation. Elements 7: 307-312

Henry DJ, Dutrow BL (1992) Tourmaline in a low grade clastic metasedimentary rock: an example of the petro- genetic potential of tourmaline. Contrib Mineral Petrol 112: 203-218

Henry DJ, Dutrow BL (1996) Metamorphic tourmaline and its petrologic applications. In: Grew ES, ANOVITZ LM (eds) Boron: Mineralogy, Petrology and Geochemistry. Mineralogical Society of America Reviews in Mineralogy 33: 503-557

Henry DJ, Guidotti CV (1985) Tourmaline as a petrogenetic indicator mineral: an example from the staurolitegrade metapelites of NW Maine. Amer Miner 70: 1-15

Henry DJ, Novák M, Hawthorne FC, Ertl A, Dutrow BL, Uher P, Pezzotta F (2011) Nomenclature of the tourmaline-supergroup minerals. Amer Miner 96: 895-913

Karlstrom KE, Bowring SA (1988) Early Proterozoic assembly of tectonostratigraphic terranes in southwestern North America. J Geol 96: 561-576

Kochelek K, McMillan NJ, McManus CE, Daniel D (2015) Provenance determination of rubies and sapphires using Laser-Induced Breakdown Spectroscopy and Multivariate Analysis. Amer Miner 100: 1921-1931

KRYNINE PD (1946) The tourmaline group in sediments. J Geol 54: 65-87

McMillan NJ, Montoya C, Chesner WH (2012) Correlation of limestone beds using Laser-Induced Breakdown Spectroscopy and chemometric analysis. Appl Opt 51: B213-B222

Nielsen KC, Scott TE JR (1979) Precambrian deformational history of the Picuris Mountains, New Mexico. In: INGERSOLL RV, WoOdWARd LA, JAMES HL (eds) Santa Fe Country. New Mexico Geological Society Fall Field Conference Guidebook 30: 113-120

SOEGAARD K, ERIKSSON KA (1985) Evidence of tide, storm, and wave interaction on a Precambrian siliciclastic shelf: the 1,700 m.y. Ortega Group, New Mexico. J Sediment Petrol 55: 672-684

SoegaArd K, Eriksson KA (1989) Origin of thick, firstcycle quartz arenite successions: evidence from the 1.7 Ga Ortega Group, northern New Mexico. Precambr Res 43: 129-141

van Hinsberg VJ (2011) Preliminary experimental data on trace-element partitioning between tourmaline and silicate melt. Canad Mineral 49: 153-163

VIATOR DB (2003) Detrital Tourmaline as an Indicator of Provenance: a Chemical and Sedimentological Study of Modern Sands from the Black Hills, South Dakota. Unpublished MSci Thesis, Louisiana State University, Baton Rouge, pp 1-139

Whitmeyer SJ, KarLSTrom KE (2007) Tectonic model for the Proterozoic growth of North America. Geosphere 3: 220-256

Wold S, SנöSTRÖm M, ERIKSSOn L (2001) PLS-regression: a basic tool of chemometrics. Chemom Intell Lab Syst 58: $109-130$ 